\title{
The changes in white matter pathways that occur in acute sports-related mild Traumatic Brain Injury
}

Remika Mito $^{1}$, Donna Parker ${ }^{1}$, David Abbott ${ }^{1,2}$, Michael Makdissi ${ }^{1,3}$, Mangor Pedersen ${ }^{2,4}$, Graeme Jackson ${ }^{1,2,5}$

\section{Author affiliations:}

1. Florey Institute of Neuroscience and Mental Health, Melbourne, Victoria, Australia

2. Florey Department of Neuroscience and Mental Health, University of Melbourne, Melbourne, Victoria, Australia

3. Olympic Park Sports Medicine Centre, Melbourne, Victoria, Australia

4. Department of Psychology and Neuroscience, Auckland University of Technology (AUT), Auckland, New Zealand

5. Department of Neurology, Austin Health, Melbourne, Victoria, Australia

Correspondence to: Remika Mito

Florey Institute of Neuroscience and Mental Health

245 Burgundy Street, Heidelberg, Victoria 3084, Australia

Email address: remika.mito@,florey.edu.au

Running title: White matter changes in acute mTBI

Keywords: concussion; mild traumatic brain injury; diffusion MRI; fixel-based analysis; white matter

Abbreviations: $A F L=$ Australian Football League; DTI = diffusion tensor imaging; DWI = diffusion-weighted imaging; FBA = fixel-based analysis; FA = fractional anisotropy; $\mathrm{FC}=$ fibre bundle cross-section; FD = fibre density; FDC = fibre density and cross-section; FOD = fibre orientation distribution; $\mathrm{MD}=$ mean diffusivity; $\mathrm{mTBI}=$ mild Traumatic Brain Injury 
medRxiv preprint doi: https://doi.org/10.1101/2022.02.07.22270651; this version posted February 9, 2022. The copyright holder for this preprint (which was not certified by peer review) is the author/funder, who has granted medRxiv a license to display the preprint in It is made available under a CC-BY-NC-ND 4.0 International license .

\section{Abstract}

Sports-related concussion, a form of mild traumatic brain injury (mTBI), is characterised by transient disturbances of brain function. There is increasing evidence that functional brain changes are driven by subtle abnormalities in white matter microstructure, and diffusion MRI has been instrumental in demonstrating these white matter abnormalities in vivo. However, the reported location and direction of the observed white matter changes in mTBI are quite variable, which is likely attributable to the inherent limitations of the white matter models used. In this cross-sectional study, we apply an advanced and robust technique known as fixel-based analysis to investigate fibre tract-specific abnormalities in professional Australian Football League players with a recent mTBI. We used the fixel-based analysis framework to identify common abnormalities found in specific fibre tracts in participants with an acute mTBI $(<2$ weeks after injury; $n=15$ ). We then assessed whether similar changes exist in subacute mTBI ( $>2$ weeks and $<3$ months after injury; $n=15$ ). The control group was 30 neurologically healthy control participants. We assessed microstructural differences in fibre density and fibre bundle morphology and performed whole-brain fixel-based analysis to compare groups. Subsequent tract-of-interest analyses were performed within five selected white matter tracts, to investigate the relationship between the observed tract-specific abnormalities and days since injury, as well as the relationship between these tract-specific changes with cognitive abnormalities. Our whole-brain analyses revealed significant increases in fibre density and bundle cross-section in acute mTBI when compared to controls. Acute mTBI showed even more extensive differences when compared to subacute mTBI than to controls. The fibre structures affected in acute mTBI included the corpus callosum, left prefrontal and left parahippocampal white matter. The fibre density and cross-sectional increases were independent of time since injury in acute mTBI, and were not associated with cognitive deficits. Overall, this study demonstrates that acute mTBI is characterised by specific white matter abnormalities, which are compatible with tract-specific cytotoxic oedema. These oedematous changes were absent in our subacute mTBI participants, although subtle abnormalities may persist in the subacute stage. 
medRxiv preprint doi: https://doi.org/10.1101/2022.02.07.22270651; this version posted February 9, 2022. The copyright holder for this preprint (which was not certified by peer review) is the author/funder, who has granted medRxiv a license to display the preprint in It is made available under a CC-BY-NC-ND 4.0 International license .

\section{Introduction}

Over the past two decades, there has been rapidly growing interest in the short- and long-term pathophysiological effects of sports-related concussion, in large part, prompted by affected high-profile athletes and forced retirements across numerous different sporting codes. Sportsrelated concussion, or mild traumatic brain injury (mTBI), is characterised by a complex cascade of neurometabolic events, which can impact brain function for days to weeks and months ${ }^{1}$. Given the absence of macroscopic abnormalities on conventional structural MRI, mTBI is considered a functional disturbance, rather than structural injury ${ }^{2,3}$. In moderate to severe TBI, however, the functional disturbances that arise are thought to be a consequence of structural damage to axonal fibre pathways within large-scale brain networks ${ }^{4,5}$. Traumatic axonal injury is a hallmark pathological feature of $\mathrm{TBI}^{6-9}$, and despite the paucity of postmortem studies in mild $\mathrm{TBI}^{10}$, there is now increasing consensus that subtle damage to white matter microstructure also underpins the functional deficits experienced in mTBI. Investigating subtle changes to white matter fibre structures in vivo could thus be valuable in the diagnosis and management of mTBI.

To this end, advances in human neuroimaging have resulted in an improved capability to examine tissue microstructure in vivo, and in particular, diffusion-weighted imaging (DWI) has provided a means to non-invasively examine white matter architecture. A particular form of DWI, known as diffusion tensor imaging (DTI), has been widely adopted by researchers to assess subtle white matter abnormalities in mTBI participants. DTI studies have identified abnormalities at various time-points following sports-related $\mathrm{mTBI}^{11-16}$. These studies have typically assessed changes to metrics such as fractional anisotropy and mean or radial diffusivity, which in more severe cases of TBI have been used as an in vivo proxy for traumatic axonal injury ${ }^{17}$. However, in mTBI, the subtle nature of neurophysiological effects means that white matter tract changes are challenging to assess, and there has correspondingly been substantial variability in the direction of detected DTI-based changes, as well as the spatial location of these abnormalities across studies ${ }^{18-22}$.

A potential explanation for the inconsistencies across DTI studies may stem from limitations to the DTI model itself. While DTI is sensitive to subtle abnormalities to white matter microstructure, it is unable to model complex or crossing-fibre populations, which account for up to $90 \%$ of white matter imaging voxels ${ }^{23}$. In the presence of such crossing-fibre structures, the same underlying pathologies could drive both increases and decreases in DTI-based 
medRxiv preprint doi: https://doi.org/10.1101/2022.02.07.22270651; this version posted February 9, 2022. The copyright holder for this preprint (which was not certified by peer review) is the author/funder, who has granted medRxiv a license to display the preprint in It is made available under a CC-BY-NC-ND 4.0 International license .

metrics $^{24-27}$. For example, a loss of axons could result in decreased fractional anisotropy; however, in the presence of unaffected crossing fibre structures, loss of axons could result in increased anisotropy in that region ${ }^{25,27}$. Indeed, in the context of mTBI, both increases ${ }^{11,13,28,29}$ and decreases ${ }^{30-32}$ in fractional anisotropy have been reported. These conflicting findings, though they have been suggested to reflect the same pathophysiological changes ${ }^{11}$, can be difficult to interpret biologically, and as such, researchers have stopped short of recommending DTI as a diagnostic biomarker in the clinical setting.

Higher-order DWI models overcome some of the limitations inherent to the DTI model and may be critical for detecting subtle white matter abnormalities in mTBI without being confounded by the presence of crossing-fibre structures. While several models are capable of estimating multiple fibre orientations within voxels ${ }^{33-35}$, one recent DWI analysis technique known as fixel-based analysis (FBA) ${ }^{36}$ additionally enables quantification of changes to specific fibre populations within voxels. FBA can be used to estimate differences in the density of fibres within a fibre bundle, as well as differences in fibre bundle cross-section, and does so at each white matter 'fixel' (specific fibre population within a voxel). By performing statistical analyses at the fixel-, rather than voxel-level, FBA can ascribe detected changes to specific white matter tracts and does not suffer from interpretability issues that crossing-fibre populations can drive when using DTI. Moreover, in the absence of potential confounds that arise due to crossing-fibre populations, FBA metrics could offer greater biological interpretability, which could be highly valuable in the clinical setting in mTBI.

In this cross-sectional study, we apply FBA to investigate fibre tract-specific abnormalities in 30 professional Australian Football League players with a recent mTBI. These professional players were available to participate in the study only when they were unable to return to training and play. This was either after acute injury before return-to-play, or sub-acutely when they had persistent symptoms that prevented them from return-to-play. This study aims to investigate whether sports-related mTBI is characterised by abnormalities within specific white matter fibre tracts at these acute and subacute stages. Additionally, we investigate the association of these fibre-specific abnormalities with time since injury and cognition in mTBI.

\section{Materials and methods}

\section{Participants}


medRxiv preprint doi: https://doi.org/10.1101/2022.02.07.22270651; this version posted February 9, 2022. The copyright holder for this preprint (which was not certified by peer review) is the author/funder, who has granted medRxiv a license to display the preprint in It is made available under a CC-BY-NC-ND 4.0 International license .

Male participants $(n=38)$ were recruited from professional Australian Football League (AFL) teams in Australia between 2012 and 2019. AFL is a sport played at speed and with a high incidence of concussion $^{37-39}$. All participants were recruited after having suffered a suspected mTBI (concussion). Concussion was diagnosed by experienced team doctors who were present at the time of injury. AFL team doctors have a consistent approach to the diagnosis and management of concussions due to ongoing research and education programs over the past 20 years $^{37,40}$.

All concussed participants were assessed at the time of injury with the Sports Concussion Assessment Tool (SCAT3), and a sideline video review was used where available ${ }^{41}$. All concussed players had clinical signs and symptoms of concussion lasting 72 hours or longer. Participants were excluded from the study where a diagnosis of concussion was not clinically confirmed $(n=2)$, or if they had suffered a more severe TBI resulting in intracranial bleedings (e.g., subdural hematoma; $n=1$ ). Participants were also excluded from the study if their MRI scan was more than 3 months after their concussion $(n=3)$, or if their MRI acquisition was incomplete $(n=2)$.

In total, 30 male professional AFL footballers were included in the study. These $30 \mathrm{mTBI}$ participants were categorised into two groups, based on the time delay from the concussion until MRI scan. Those participants who had their MRI scan $\leq 14$ days since concussion were categorised into an acute mTBI group $(n=15)$, while those whose MRI scan was $>14$ days since concussion were categorised into a subacute mTBI group $(n=15)$. Given that all mTBI participants were professional athletes with substantial training commitments, involvement in the study was possible when the footballers had not yet returned to training and competition. This meant that participants categorised into the subacute mTBI group tended to have persistent symptoms lasting beyond 14 days, which prevented them from return-to-play.

Healthy control participants were recruited for the study, or selected from previously acquired DWI control data obtained at our institute $(n=30)$. For each mTBI participant, a male control participant was selected who matched the mTBI participant in age and scanner on which the MRI was acquired.

All participants provided written informed consent before participation in the study. The study was approved by the human research ethics committees at the University of Melbourne (ID: 0830367) and at Austin Health (ID: 49573/2019). 
medRxiv preprint doi: https://doi.org/10.1101/2022.02.07.22270651; this version posted February 9, 2022. The copyright holder for this preprint (which was not certified by peer review) is the author/funder, who has granted medRxiv a license to display the preprint in It is made available under a CC-BY-NC-ND 4.0 International license .

\section{MRI data acquisition}

All participants underwent an MRI scan at the Florey Institute of Neuroscience and Mental Health, which included high angular resolution diffusion-weighted imaging (DWI) acquisition. MRI data were acquired at 3T on a Siemens Skyra with a 20-channel head coil receiver (Erlangen, Germany) for the majority of participants. Echo planar imaging DWI data were acquired on the Skyra with 60 axial slices, TR/TE $=8400 / 110 \mathrm{~ms}, 2.5 \mathrm{~mm}$ isotropic voxels, 64 diffusion-weighted images $\left(b=3000 \mathrm{~s} / \mathrm{mm}^{2}\right)$ and at least $1 \mathrm{~b}=0$ image. Equivalent DWI were acquired on a Siemens Tim Trio with a 12-channel head coil receiver for two acute mTBI participants (and two matched healthy controls) with the following parameters: 60 axial slices, $\mathrm{TR} / \mathrm{TE}=8300 / 110 \mathrm{~ms}, 2.5 \mathrm{~mm}$ isotropic voxels, 60 diffusion-weighted images $(\mathrm{b}=3000$ $\mathrm{s} / \mathrm{mm}^{2}$ ) and $8 \mathrm{~b}=0$ images. A reverse phase-encoded $\mathrm{b}=0$ image was acquired in all cases to correct for B0-field inhomogeneities.

Isotropic T1-weighted magnetization-prepared acquisition gradient echo (MPRAGE) images were also acquired from all participants with the following parameters: TR/TE $=1900 / 2.5 \mathrm{~ms}$, inversion time $=900 \mathrm{~ms}$, flip angle $=9^{\circ}$, voxel size $=0.9 \mathrm{~mm}^{3}$, acquisition matrix $256 \times 256 \mathrm{x}$ 192. Intracranial volume was computed from T1 images using SPM12 $2^{42}$.

\section{Diffusion-weighted image processing}

All DWI data were pre-processed and analysed using MRtrix ${ }^{43}$, using commands implemented in MRtrix3, or using MRtrix3 scripts that interfaced with external software packages.

Pre-processing of diffusion-weighted images included denoising ${ }^{44}$ and Gibbs ringing removal ${ }^{45}$. Following this, eddy-current and motion correction was performed using FSL's "eddy" tool. Susceptibility-induced off-resonance fields were estimated using the different phase-encoded $b=0$ images ${ }^{46}$, after which gross subject movement and eddy-current induced distortions were estimated $^{47}$. The quality of the diffusion datasets was assessed using eddy QC tools ${ }^{48}$. Estimates of subject motion obtained from eddy QC were used to determine whether groups differed in motion. Bias field correction was then performed ${ }^{49}$, and diffusion-weighted images were finally upsampled to a voxel size of $1.3 \mathrm{~mm}^{2}$ using cubic b-spline interpolation ${ }^{50}$.

Following these pre-processing steps, fibre orientation distribution (FOD) functions were computed using Single-Shell, 3-Tissue Constrained Spherical Deconvolution (SS3T-CSD ${ }^{51}$ ), 
medRxiv preprint doi: https://doi.org/10.1101/2022.02.07.22270651; this version posted February 9, 2022. The copyright holder for this preprint (which was not certified by peer review) is the author/funder, who has granted medRxiv a license to display the preprint in It is made available under a CC-BY-NC-ND 4.0 International license .

with group-averaged response functions for white matter, grey matter and CSF, using MRtrix3Tissue (http://3Tissue.github.io). Joint bias field and intensity normalisation were then performed.

A study-specific population template image was generated using FOD images from a subset of participants who were randomly selected from the study cohort. FOD images from 40 participants (10 acute mTBI, 10 subacute mTBI, 20 controls) were used to generate a population template image using an iterative registration and averaging approach ${ }^{52}$. FOD images from all subjects were then registered to the unbiased template image using FODguided non-linear registration ${ }^{52,53}$.

A whole-brain tractogram was generated using probabilistic tractography on the population template. Twenty million streamlines were generated, which were subsequently filtered to 2 million streamlines to reduce reconstruction biases using the SIFT algorithm ${ }^{54}$.

\section{Fixel-based analysis}

Abnormalities in white matter pathways were assessed using the fixel-based analysis (FBA) framework $^{36}$, whereby the term 'fixel' refers to a specific fibre population within a voxel. In brief, this involved computing measures of apparent fibre density (FD), fibre bundle crosssection (FC), and a combined metric of fibre density and cross-section (FDC) for each subject at each white matter fixel in template space.

FD was computed according to the Apparent Fibre Density framework ${ }^{50}$, whereby a quantitative measure of fibre density can be derived from FOD images, as the integral of the FOD along a given direction is proportional to the intra-axonal volume of axons aligned in that direction. FD values for each subject at each fixel were assigned to the template fixel mask so that FD could be compared across groups in corresponding fixels. FC was computed for each fixel by using the non-linear warps to compute the change in FC required to normalise each subject to the template image. Finally, the FDC metric combined both sources of information (FD and FC), to estimate both density and cross-sectional changes in specific white matter pathways.

\section{Cognitive assessment}

Cognitive testing was performed at the time of the MRI scan using CogSport, a computerised cognitive test battery (CogState Ltd, Melbourne, Victoria, Australia). The battery comprised 
medRxiv preprint doi: https://doi.org/10.1101/2022.02.07.22270651; this version posted February 9, 2022. The copyright holder for this preprint (which was not certified by peer review) is the author/funder, who has granted medRxiv a license to display the preprint in It is made available under a CC-BY-NC-ND 4.0 International license .

of four tasks: simple reaction time, complex reaction time, one-back, and continuous learning, which have previously been shown to be sensitive to the cognitive effects of concussion in sport $^{55,56}$. These tasks are designed to assess psychomotor function, decision making, working memory, and learning, respectively. Normalised scores from these tests based on neurologically normal healthy individuals ${ }^{57}$ (where 100 reflects the mean score from healthy individuals) were used in subsequent regression analyses to examine the relationship between fibre-specific changes and cognition.

\section{Statistical analysis}

\section{Whole-brain fixel-based analysis}

Whole-brain fixel-based analysis was performed to compare measures of FD, FC, and FDC in the three groups of interest (acute mTBI, subacute mTBI and controls). Statistical comparisons of these fixel-based metrics were performed between groups at each white matter fixel using a General Linear Model, by performing the following group-wise comparisons: (i) acute mTBI versus controls; (ii) subacute mTBI versus controls; and (iii) acute mTBI versus subacute mTBI. Age and intracranial volume were included as nuisance covariates, but not scanner type due to the unbalanced number of participants on the two scanner types. Connectivity-based smoothing and statistical inference were performed using connectivity-based fixel enhancement (CFE), using 2 million streamlines from the template tractogram and default smoothing parameters $(\text { smoothing }=10 \mathrm{~mm} \text { full-width half-maximum })^{58}$. Family-wise error (FWE)-corrected $\mathrm{p}$ values were assigned to each fixel using non-parametric permutation testing over 5000 permutations $^{59}$.

\section{Tract-of-interest regression analyses}

The fixels that exhibited significant differences in our whole-brain fixel based analyses were selected for exploratory post-hoc tract-of-interest analyses.

\section{Association with clinical measures}

For post-hoc analyses with clinical measures, there were five fixel clusters selected: the genu, splenium, and body of the corpus callosum, left frontal white matter (WM) cluster, and left parahippocampal/isthmus WM cluster. These fixel clusters were selected from significant results from whole-brain FBA: between the acute mTBI and control groups for the genu and 
medRxiv preprint doi: https://doi.org/10.1101/2022.02.07.22270651; this version posted February $9,2022$. The copyright holder for this preprint (which was not certified by peer review) is the author/funder, who has granted medRxiv a license to display the preprint in It is made available under a CC-BY-NC-ND 4.0 International license .

left parahippocampal/isthmus cluster; and between the acute and subacute mTBI groups for the remaining three fixel clusters (the splenium, the body of corpus callosum, and left frontal WM cluster). Mean FD, FC and/or FDC values were computed within each of these five tract clusters, for the fixel-based metrics that exhibited a significant difference upon whole-brain FBA (i.e., if significant differences were only observed in a given cluster for the FD metric, only FD was examined for these post-hoc analyses). Given that post-hoc regression analyses were performed only in the mTBI participants, we then expressed FD, FC, and FDC values as a percentage change in the mTBI participants from the control group mean.

Exploratory post-hoc linear models were performed within the acute mTBI cohort, to examine the relationship between mean $\mathrm{FD} / \mathrm{FC} / \mathrm{FDC}$ in the five fixel clusters with time since injury. Intracranial volume was included as a covariate in these analyses (given the likely association between FC and head size, and inherent interdependency of FD, FC, and FDC), and Bonferroni correction used to correct for the five tract comparisons.

We then explored the relationship between mean FD/FC/FDC in the five fixel clusters and cognitive scores across the mTBI cohort (both acute and subacute mTBI). Here, linear models were performed to examine the relationship between mean fixel-based metrics within each of the five fixel clusters, and normative scores (expressed as a percentage of the mean value from a healthy control sample) for the four cognitive tests (assessing psychomotor function, decision making, working memory, and learning). Intracranial volume was again included as a covariate in these analyses, and Bonferroni correction used to correct for the five tract comparisons.

All post-hoc statistical analyses were performed in $\mathrm{R}$ (version 3.6.3).

\section{Data availability}

The data that support the findings of this study are available upon reasonable request from the corresponding author. The data are not publicly available as they include participant data that could compromise the privacy of participants.

\section{Results}

\section{Participants}

Mito et al. 
medRxiv preprint doi: https://doi.org/10.1101/2022.02.07.22270651; this version posted February 9, 2022. The copyright holder for this preprint (which was not certified by peer review) is the author/funder, who has granted medRxiv a license to display the preprint in It is made available under a CC-BY-NC-ND 4.0 International license .

Participant demographics are available in Table 1. The professional athletes in the acute mTBI group had a mean age $( \pm$ SD) of $23.93( \pm 3.37)$, and had all been scanned within 2 weeks of injury, with a mean delay since the injury of 7.47 days $( \pm 3.25)$. Athletes in the subacute mTBI group had a mean age of $25.18( \pm 3.45)$, and had all been scanned later than two weeks but within 3 months of injury, with a mean delay between MRI scan and injury of 34.33 days $( \pm$ 19.4). There were no significant differences between the three groups in age, intracranial volume, or DWI motion, although the subacute mTBI group had marginally higher intracranial volume than the acute mTBI and control groups (Table 1).

Athletes in the acute and subacute mTBI groups had comparable years of professional sporting career, and did not differ substantially in CogSport cognitive test measures at the time of MRI scan (Table 1).

\section{Whole-brain fixel-based analysis}

Figure 1 shows the fixel-wise pattern of fibre density and cross-section (FDC) differences when comparing the three groups (acute mTBI, subacute mTBI, and control groups), coloured by family-wise error (FWE)-corrected p-value. While increased FDC was observed in the acute mTBI group when compared to both the control and subacute mTBI groups, predominantly in callosal fibre structures, there was no evidence of decreased FDC in the acute mTBI group when compared to the other groups. In contrast, we did not observe any significant increases in FDC in the subacute mTBI group when compared to controls or acute mTBI. Some fibre structures appeared to have lowered FDC in the subacute mTBI group (namely, the left fornix); however, these did not survive FWE correction.

Participants with acute mTBI had a small number of fixels with a statistically significant increase in fibre density (FD) compared to controls, in the left posterior parahippocampal white matter extending into the isthmus (FWE-corrected $p$-value $<0.05)$. A significant increase in FDC was also observed in the acute mTBI group compared to controls in the genu and body of the corpus callosum (Figure 2).

No significant changes were observed in the subacute mTBI group when compared to controls, in any of the fixel-based metrics.

Fibre-specific increases appeared to be characteristic of the early stages of mTBI, given that significant differences in the fixel-based metrics were observed when comparing those with a recent concussion ( $\leq 14$ days post-concussion; acute $\mathrm{mTBI}$ ) to those with a longer delay since 
medRxiv preprint doi: https://doi.org/10.1101/2022.02.07.22270651; this version posted February 9, 2022. The copyright holder for this preprint (which was not certified by peer review) is the author/funder, who has granted medRxiv a license to display the preprint in It is made available under a CC-BY-NC-ND 4.0 International license .

concussion ( $>14$ days post-concussion; subacute mTBI). Figure 3 shows the fibre-specific differences between the acute and subacute mTBI groups, for each of the three fixel-based metrics. Significantly greater FD was observed in the acute mTBI group compared to the subacute mTBI group in the splenium of the corpus callosum, as well as in select fixels within the left posterior parahippocampal white matter. Greater FC was also evident in the acute mTBI group in the splenium, as well as in an area of left frontal white matter within the superior longitudinal fasciculus. Significant increases in FDC were observed in the acute mTBI group in the fibre tracts affected by the FD and FC metrics - the splenium and left frontal white matter-as well as in the body of the corpus callosum at the level of the motor cortices.

\section{Tract-of-interest analyses}

Fixels that exhibited significant changes in the acute mTBI group when compared to either the control or subacute mTBI groups were grouped into five tract clusters. These tracts-of-interest are shown in Figure 4. Within the acute mTBI group, we did not observe any significant associations between fixel-based metrics in the tracts-of-interest with days since injury.

Cognitive data was available for $23 \mathrm{mTBI}$ participants, while it was unavailable for 7 participants, who were excluded from these analyses. We did not observe any significant associations between mean fixel-based measures in the tracts of interest with cognitive test scores (see Supplementary Table 1). Scatterplots showing the relationship between fixel-based measures in the select tracts and normative cognitive test scores are available in the Supplementary Material (Figures S1-S4).

\section{Discussion}

In this study, we applied advanced diffusion MRI methodology to investigate fibre tractspecific white matter abnormalities in professional athletes after an mTBI. The major findings of our work were that: (i) participants with acute mTBI exhibit abnormalities in selected fibre tracts, which can be interpreted as white matter tract-specific cytotoxic oedema; and (ii) these fibre-specific abnormalities do not seem to persist into the subacute stage beyond two weeks after injury, even when symptoms may persist. 


\section{Acute mTBI is characterised by abnormalities in specific white matter tracts}

Abnormalities were observed in specific fibre pathways in acute mTBI participants when compared to control participants in this study, as measured by increases in fibre density and cross-section. Significant changes occurred in the left posterior parahippocampal white matter, and the genu and body of the corpus callosum. Moreover, when comparing acute mTBI to subacute mTBI participants, fibre density and cross-section were also found to be elevated in additional white matter structures: within the splenium of the corpus callosum and left frontal white matter of the superior longitudinal fasciculus.

The location of these tract-specific white matter abnormalities is in line with the body of mTBI literature using DTI, in which certain fibre structures like the corpus callosum have consistently been implicated $^{11,16,30,60,61}$, despite variability in other neuroanatomical locations involved ${ }^{18,20}$. Indeed, callosal structures and midline white matter tracts appear to be preferentially vulnerable to traumatic axonal injury, as has been demonstrated in post-mortem studies ${ }^{6}$, animal models ${ }^{62}$, as well as laboratory reconstructions of sports-related concussions ${ }^{63}$.

In addition to midline structures, we observed significant abnormalities within the left prefrontal white matter and left parahippocampal white matter, but not in any right hemisphere white matter structures. This is consistent with several studies in $\mathrm{mTBI}^{29,61,64}$ and TBI more broadly ${ }^{65,66}$ that suggest there is greater left hemisphere abnormality than right. The same left hemisphere fibre tracts that have been shown to exhibit abnormalities in DTI studies in mTBI have also shown leftward asymmetry in healthy individuals ${ }^{67,68}$, whereby higher white matter integrity has been reported. Some have hypothesised that this asymmetry may render these white matter regions more vulnerable to sports-related $\mathrm{mTBI}^{64}$. Alternatively, it may be that left-sided injury with verbal disturbance is more often diagnosed as concussion, and overrepresented in these cohorts. Interestingly, in a recent case study from our cohort, increased water content (MRI-T2 relaxometry) was observed within the left frontal white matter, which we suggested reflects selective vulnerability to post-concussive neuroinflammation or oedema in this brain region ${ }^{69}$.

\section{Increases rather than decreases in fibre density and cross-section in acute $\mathrm{mTBI}$}


medRxiv preprint doi: https://doi.org/10.1101/2022.02.07.22270651; this version posted February 9, 2022. The copyright holder for this preprint (which was not certified by peer review) is the author/funder, who has granted medRxiv a license to display the preprint in It is made available under a CC-BY-NC-ND 4.0 International license .

While there is increasing consensus about which white matter fibre tracts that are affected in mTBI, both increases and decreases in the same DTI-based metrics have been reported, making biological interpretation difficult. In the present study, we observed significant increases rather than decreases in fibre density and cross-section (a fixel-based, rather than DTI-based metric) in the acute mTBI group. Decreases in this fibre density metric can be interpreted as a loss of axons ${ }^{36,50}$, while increases in fibre density can be interpreted as an increase in the total intraaxonal volume occupied by fibre structures aligned in a given direction, even in the presence of crossing-fibre pathways ${ }^{50}$. In the present context, our finding of increased FD is entirely compatible with cytotoxic oedema in these fibre structures, whereby an increase in membrane permeability could result in axonal swelling ${ }^{70-72}$, and larger axonal diameters ${ }^{73}$ (see Figure 5). In the presence of enlarged axons, fibre bundles could also increase in cross-section, which would drive the observed increases in the FC metric.

DTI studies in which increased fractional anisotropy has been reported have similarly suggested that mTBI is characterised by cytotoxic oedema ${ }^{28,74,75}$. In longitudinal DTI studies, persistent FA increases (and/or MD decreases) have been observed at the acute, subacute and chronic stages following injury, for up to 6 months ${ }^{11,14,76}$. The chronic nature of increases in FA has raised questions about its interpretability as cytotoxic oedema ${ }^{76}$, particularly if the inflammatory process were to be followed by necrotic cell death ${ }^{77}$. Chronically increased FA, however, may be misleading, as the same direction of FA changes in the acute and chronic stages following mTBI could arise from different processes, for example, the loss of crossing fibre structures in the chronic phase of the injury ${ }^{11}$.

In our study, the increases in fixel-based metrics observed in the acute mTBI group did not appear to persist into the subacute stage. Indeed, if anything, our findings suggest there may be subtle decreases in fibre density and cross-section by the subacute stage (Figure 1), given the greater extent of significant fixel-based differences between the acute and subacute mTBI groups than between the acute mTBI and control groups. Such a finding is in line with a metaanalysis of DTI studies in mTBI that suggest the direction of anisotropy changes may relate to timing since injury ${ }^{22}$. This would be compatible with an oedematous process, whereby cytotoxic oedema in the acute stage is followed by axonal loss at later time points. Alternatively, oedema may be followed by recovery of neurons ${ }^{78}$, and indeed faster recovery profiles have been suggested to be characteristic of professional athletes who are exposed to repeated concussive events $^{79}$. It is also possible that a given individual could follow one of these two trajectories: (1) recovery following transient inflammation and/or oedema; or (2) cytotoxic 
medRxiv preprint doi: https://doi.org/10.1101/2022.02.07.22270651; this version posted February 9, 2022. The copyright holder for this preprint (which was not certified by peer review) is the author/funder, who has granted medRxiv a license to display the preprint in It is made available under a CC-BY-NC-ND 4.0 International license .

oedema followed by neuronal loss due to axotomy. Thus, the trajectory of changes in fixelbased metrics may predict clinical recovery in that individual.

\section{The clinical significance of fibre-specific increases in acute mTBI}

There is some evidence from DTI studies to suggest that inflammatory processes in acute mTBI may relate to symptom severity and clinical outcomes ${ }^{28,74,75}$. In the present study, while we hypothesised that fibre density and cross-sectional increases observed in the acute mTBI group would relate to cognitive abnormalities, we did not find any evidence to support this.

Cognitive abnormalities and symptom severity following mTBI are generally quite transient, with longitudinal studies showing abnormal clinical measures evident at 24 to 48 hours normalising by 8 or 9 days following concussion ${ }^{13,14,16}$. Given that our acute mTBI group had a mean time since the injury of 7.5 days (Table 1), it is likely that any cognitive abnormalities that may have been evident in this group would have normalised by the time of our clinical assessment. This may explain why we did not observe any significant associations between the fibre-specific abnormalities in the acute mTBI group with reduced cognitive scores. It should be noted that in DTI studies, clinical signs and symptoms, rather than cognitive performance, have been shown to be more sensitively related to brain injury, as measured by increases in fractional anisotropy ${ }^{28,75}$.

Within the acute mTBI group, we also did not find any evidence of an association between tract-specific abnormalities and days since injury. It is possible that we were under-powered to observe such an association within the acute mTBI group. Moreover, it is difficult to assess the relationship of these tract-specific changes with time in a cross-sectional study design. Nonetheless, given that tract-specific measures were not markedly elevated in individuals at the subacute stage of injury, these tract-specific increases could be considered a useful marker of the early stage (first two weeks) of mTBI, irrespective of time since injury.

\section{Technical advantages of fixel-based analysis}

One of the major advantages of applying fixel-based analysis to investigate mTBI is that its fibre-specific nature offers greater interpretability than more commonly used approaches such as DTI. Changes in DTI-based metrics such as fractional anisotropy and mean diffusivity are potentially attributable to a range of non-specific causes, including partial volume effects ${ }^{80}$, loss of crossing-fibre populations ${ }^{25,27}$, and gliosis ${ }^{81}$. This can result in difficulty interpreting 
medRxiv preprint doi: https://doi.org/10.1101/2022.02.07.22270651; this version posted February 9, 2022. The copyright holder for this preprint (which was not certified by peer review) is the author/funder, who has granted medRxiv a license to display the preprint in It is made available under a CC-BY-NC-ND 4.0 International license .

the clinical significance of DTI-based findings. In the present study, due to how diffusion MRI data have been acquired, modelled, and analysed, we can better interpret changes in fibre density and cross-section (see Figure 5).

While DTI has been applied to detect axonal injury in individuals with moderate to severe $\mathrm{TBI}^{82}$, no neuroimaging tools currently exist that can diagnose $\mathrm{mTBI}$ in individuals ${ }^{21}$. It has been suggested that DTI possesses adequate sensitivity to detect white matter abnormalities in mTBI at both acute and subacute stages using group analyses ${ }^{18}$; however, the inherent biases introduced by voxel-based analyses and tract-based spatial statistics (TBSS) make their use for detection of mTBI in individual subjects inappropriate ${ }^{83}$. In this regard, fixel-based analysis may prove valuable, as it enables the detection of highly localised, yet important tract-specific changes-such as those observed here in the left parahippocampal white matter-without being confounded by the presence of crossing-fibre populations. Moreover, if fibre-specific changes follow a dynamic trajectory over time (as our cross-sectional findings suggest), FBA may be valuable in guiding safe return-to-play following injury in the future.

It should be noted that there have been various advanced diffusion methods that have been developed over the past decade. Some mTBI studies have implemented more advanced diffusion models including diffusion kurtosis imaging (DKI) and neurite orientation dispersion and density imaging (NODDI) ${ }^{14,84-88}$. However, the major advantage of FBA is that it moves entirely beyond a tensor-based model in which comparisons are inherently voxel-averaged, to using a fibre tract-specific model which enables more directly interpretable measures of structural connectivity ${ }^{36}$. FBA has now been applied across numerous neurological disorders ${ }^{89}$, as well as in recent TBI studies ${ }^{90-92}$. Of note, our findings corroborate recent work in a small cohort of Australian Rules footballers that has similarly reported increases in fixel-based metrics in concussed individuals ${ }^{93}$.

\section{Limitations and future directions}

While we argue that FBA presents a major technical advantage, there are limitations pertaining to our study cohort. Our findings are based on a relatively small cohort of mTBI participants, and although we had a well-matched sample of control participants, demographic measures that could influence fibre-specific measures (such as years of education) were not available for these participants. Our study included a highly controlled cohort of professional athletes, in whom findings may not be generalisable to other TBI cohorts. 
medRxiv preprint doi: https://doi.org/10.1101/2022.02.07.22270651; this version posted February 9, 2022. The copyright holder for this preprint (which was not certified by peer review) is the author/funder, who has granted medRxiv a license to display the preprint in It is made available under a CC-BY-NC-ND 4.0 International license .

Professional AFL players often report numerous concussions during their sporting careers ${ }^{69}$, and there is increasing evidence regarding the deleterious effects of repeat concussions ${ }^{94,95}$. However, in this study, we were unable to account for the number of previous concussions, as this self-reported and often unreliable data was not available for all participants. Despite this, the subacute mTBI cohort used in this study can in many ways be considered an almost ideal control cohort for the acute mTBI participants, given that they were professional athletes likely to be well-matched in demographic measures, concussion history, sporting ability and training requirements. The similarities in the affected fibre pathways when comparing the acute and subacute mTBI groups, to when we compared the acute mTBI to healthy control cohort, provides comfort that these changes relate to acute effects of mTBI, and not to other potential differences between the acute and healthy control participants.

Finally, while we hypothesise on the potential trajectory of fibre-specific changes over the acute and subacute stages of mTBI, we cannot assess the temporal changes with our crosssectional data. Given that this study included professional athletes who were recruited by team doctors, their inclusion in the study was potentially driven by concern from the medical professionals who assessed their recovery and was also only possible when athletes did not have substantial training and competition commitments. The acute mTBI group represented a cohort of professional athletes recruited during their mandated rest period. However, participants in the subacute mTBI group (more than 2 weeks after injury) were likely recruited due to poor recovery or persistent symptomatology. The subtle abnormalities detected in the subacute stage in our cohort may be characteristic to those with poor recovery or persistent symptoms (Figure 1). Future work investigating the longitudinal trajectory of fibre-specific changes across acute and subacute stages will be invaluable in this regard.

\section{Conclusions}

Acute mTBI is characterised by subtle abnormality in select fibre structures. The location and direction of these fibre-specific changes are consistent with previous literature, and our findings support the theory of cytotoxic oedema in the days to weeks following mTBI. However, we did not find evidence to suggest that these fibre tract changes in the first two weeks following injury are associated with cognitive deficits nor time since injury. Future work incorporating fixel-based analysis into longitudinal studies will be critical for further understanding these changes including the time course of these fibre tract changes following sports-related mTBI. 
medRxiv preprint doi: https://doi.org/10.1101/2022.02.07.22270651; this version posted February 9, 2022. The copyright holder for this preprint (which was not certified by peer review) is the author/funder, who has granted medRxiv a license to display the preprint in It is made available under a CC-BY-NC-ND 4.0 International license .

\section{Acknowledgements}

The authors wish to thank the Australian Football League (AFL) Doctors Association, AFL Players Association, Dr Patrick Clifton (former AFL Operations and Innovations Manager) and Dr Peter Harcourt (former AFL Medical Director) for their support of the project. We also thank all the recruited participants who gave their valuable time to participate in this study. The Florey Institute of Neuroscience and Mental Health acknowledges the strong support from the Operational Infrastructure Support Grant. We also acknowledge the facilities, and the scientific and technical National Collaborative Research Infrastructure Strategy (NCRIS) capability at the Florey node, and the Victorian Biomedical Imaging Capability (VBIC).

\section{Author contributions}

Remika Mito: Conceptualization, Formal analysis, Visualization, Writing - Original Draft; Donna Parker: Investigation, Resources, Project administration, Data curation; David Abbott: Resources, Project administration, Funding acquisition, Writing - Review \& Editing; Michael Makdissi: Investigation, Resources, Project administration, Data curation, Funding acquisition; Mangor Pedersen: Conceptualization, Writing - Review \& Editing, Supervision; Graeme Jackson: Conceptualization, Funding acquisition, Writing - Review \& Editing, Supervision.

\section{Funding}

This study was supported in part by the National Health and Medical Research Council (NHMRC) of Australia (G.J. Practitioner Fellowship; grant number \#1060312). R.M. is supported by grants from Brain Australia and the Brain Foundation. D.A. is supported by fellowship funding from the National Imaging Facility. M.P. is supported by an Emerging Grant Fellowship from the Health Research Council. Funding for the MRI scans was provided by the AFL.

\section{Competing interests}

Dr Michael Makdissi is a consultant Sport and Exercise Medicine physician at Olympic Park Sports Medicine Centre and Chief Medical Officer for the Australian Football League (AFL). 
medRxiv preprint doi: https://doi.org/10.1101/2022.02.07.22270651; this version posted February 9, 2022. The copyright holder for this preprint (which was not certified by peer review) is the author/funder, who has granted medRxiv a license to display the preprint in It is made available under a CC-BY-NC-ND 4.0 International license

He is a member of the International Concussion in Sport Group. He has previously received research funding from the AFL and non-financial research support from CogState Pty Ltd. He has attended meetings organised by the International Olympic Committee, the National Football League (USA), the National Rugby League (Australia), and FIFA (Switzerland); however, has not received any payment, research funding, or other monies from these groups other than for travel costs. He is an honorary member of concussion working/advisory groups for the Australian Rugby Union and World Rugby. The remaining authors report no competing interests. 
medRxiv preprint doi: https://doi.org/10.1101/2022.02.07.22270651; this version posted February 9, 2022. The copyright holder for this preprint (which was not certified by peer review) is the author/funder, who has granted medRxiv a license to display the preprint in It is made available under a CC-BY-NC-ND 4.0 International license.

\section{References}

1. Giza, C.C., and Hovda, D.A. (2014). The new neurometabolic cascade of concussion. Neurosurgery 75, S24-S33.

2. McCrory, P., Meeuwisse, W., Dvorak, J., Aubry, M., Bailes, J., Broglio, S., Cantu, R.C., Cassidy, D., Echemendia, R.J., and Castellani, R.J. (2017). Consensus statement on concussion in sport - the 5th international conference on concussion in sport held in Berlin, October 2016. Br. J. Sports Med. 51, 838-847.

3. Jackson, G.D., Makdissi, M., Pedersen, M., Parker, D.M., Curwood, E.K., Farquharson, S., Connelly, A., Abbott, D.F., and McCrory, P. (2019). Functional brain effects of acute concussion in Australian rules football players. J. concussion 3, 2059700219861200.

4. Sharp, D.J., Scott, G., and Leech, R. (2014). Network dysfunction after traumatic brain injury. Nat. Rev. Neurol. 10, 156.

5. Fagerholm, E.D., Hellyer, P.J., Scott, G., Leech, R., and Sharp, D.J. (2015).

Disconnection of network hubs and cognitive impairment after traumatic brain injury. Brain 138, 1696-1709.

6. Adams, J.H., Doyle, D., Ford, I., Gennarelli, T.A., Graham, D.I., and McLellan, D.R. (1989). Diffuse axonal injury in head injury: definition, diagnosis and grading. Histopathology 15, 49-59.

7. Alexander, M.P. (1995). Mild traumatic brain injury: pathophysiology, natural history, and clinical management. Neurology .

8. Povlishock, J.T., and Katz, D.I. (2005). Update of neuropathology and neurological recovery after traumatic brain injury. J. Head Trauma Rehabil. 20, 76-94.

9. Johnson, V.E., Stewart, W., and Smith, D.H. (2013). Axonal pathology in traumatic brain injury. Exp. Neurol. 246, 35-43.

10. Blumbergs, P.C., Scott, G., Manavis, J., Wainwright, H., Simpson, D.A., and McLean, A.J. (1994). Stalning af amyloid percursor protein to study axonal damage in mild head Injury. Lancet 344, 1055-1056.

11. Henry, L.C., Tremblay, J., Tremblay, S., Lee, A., Brun, C., Lepore, N., Theoret, H., Ellemberg, D., and Lassonde, M. (2011). Acute and chronic changes in diffusivity measures after sports concussion. J. Neurotrauma 28, 2049-2059.

12. Bazarian, J.J., Zhu, T., Blyth, B., Borrino, A., and Zhong, J. (2012). Subject-specific changes in brain white matter on diffusion tensor imaging after sports-related concussion. Magn. Reson. Imaging 30, 171-180.

13. Meier, T.B., Bergamino, M., Bellgowan, P.S.F., Teague, T.K., Ling, J.M., Jeromin, A., and Mayer, A.R. (2016). Longitudinal assessment of white matter abnormalities following sports-related concussion. Hum. Brain Mapp. 37, 833-845.

14. Lancaster, M.A., Meier, T.B., Olson, D. V, McCrea, M.A., Nelson, L.D., and Muftuler, L.T. (2018). Chronic differences in white matter integrity following sportrelated concussion as measured by diffusion MRI: 6-Month follow-up. Hum. Brain Mapp. 39, 4276-4289.

15. Mustafi, S.M., Harezlak, J., Koch, K.M., Nencka, A.S., Meier, T.B., West, J.D., Giza, 
medRxiv preprint doi: https://doi.org/10.1101/2022.02.07.22270651; this version posted February 9, 2022. The copyright holder for this preprint (which was not certified by peer review) is the author/funder, who has granted medRxiv a license to display the preprint in It is made available under a CC-BY-NC-ND 4.0 International license .

C.C., DiFiori, J.P., Guskiewicz, K.M., and Mihalik, J.P. (2018). Acute white-matter abnormalities in sports-related concussion: a diffusion tensor imaging study from the NCAA-DoD CARE Consortium. J. Neurotrauma 35, 2653-2664.

16. Wu, Y.-C., Harezlak, J., Elsaid, N.M.H., Lin, Z., Wen, Q., Mustafi, S.M., Riggen, L.D., Koch, K.M., Nencka, A.S., and Meier, T.B. (2020). Longitudinal white-matter abnormalities in sports-related concussion: A diffusion MRI study. Neurology 95, e781-e792.

17. Graham, N.S.N., Jolly, A., Zimmerman, K., Bourke, N.J., Scott, G., Cole, J.H., Schott, J.M., and Sharp, D.J. (2020). Diffuse axonal injury predicts neurodegeneration after moderate-severe traumatic brain injury. Brain 143, 3685-3698.

18. Gardner, A., Kay-Lambkin, F., Stanwell, P., Donnelly, J., Williams, W.H., Hiles, A., Schofield, P., Levi, C., and Jones, D.K. (2012). A systematic review of diffusion tensor imaging findings in sports-related concussion. J. Neurotrauma 29, 2521-2538.

19. McCrea, M., Meier, T., Huber, D., Ptito, A., Bigler, E., Debert, C.T., Manley, G., Menon, D., Chen, J.-K., and Wall, R. (2017). Role of advanced neuroimaging, fluid biomarkers and genetic testing in the assessment of sport-related concussion: a systematic review. Br. J. Sports Med. 51, 919-929.

20. Shenton, M.E., Hamoda, H.M., Schneiderman, J.S., Bouix, S., Pasternak, O., Rathi, Y., Vu, M.-A., Purohit, M.P., Helmer, K., and Koerte, I. (2012). A review of magnetic resonance imaging and diffusion tensor imaging findings in mild traumatic brain injury. Brain Imaging Behav. 6, 137-192.

21. Jordan, B.D. (2013). The clinical spectrum of sport-related traumatic brain injury. Nat. Rev. Neurol. 9, 222.

22. Eierud, C., Craddock, R.C., Fletcher, S., Aulakh, M., King-Casas, B., Kuehl, D., and LaConte, S.M. (2014). Neuroimaging after mild traumatic brain injury: review and meta-analysis. NeuroImage Clin. 4, 283-294.

23. Jeurissen, B., Leemans, A., Tournier, J., Jones, D.K., and Sijbers, J. (2013). Investigating the prevalence of complex fiber configurations in white matter tissue with diffusion magnetic resonance imaging. Hum. Brain Mapp. 34, 2747-2766.

24. Jones, D.K. (2010). Challenges and limitations of quantifying brain connectivity in vivo with diffusion MRI. Imaging Med. 2, 341-355.

25. Douaud, G., Jbabdi, S., Behrens, T.E.J., Menke, R.A., Gass, A., Monsch, A.U., Rao, A., Whitcher, B., Kindlmann, G., and Matthews, P.M. (2011). DTI measures in crossing-fibre areas: increased diffusion anisotropy reveals early white matter alteration in MCI and mild Alzheimer's disease. Neuroimage 55, 880-890.

26. Jones, D.K., Knösche, T.R., and Turner, R. (2013). White matter integrity, fiber count, and other fallacies: the do's and don'ts of diffusion MRI. Neuroimage 73, 239-254.

27. Mito, R., Raffelt, D., Dhollander, T., Vaughan, D.N., Tournier, J.-D., Salvado, O., Brodtmann, A., Rowe, C.C., Villemagne, V.L., and Connelly, A. (2018). Fibrespecific white matter reductions in Alzheimer's disease and mild cognitive impairment. Brain 141, 888-902.

28. Bazarian, J.J., Zhong, J., Blyth, B., Zhu, T., Kavcic, V., and Peterson, D. (2007). Diffusion tensor imaging detects clinically important axonal damage after mild traumatic brain injury: a pilot study. J. Neurotrauma 24, 1447-1459. 
medRxiv preprint doi: https://doi.org/10.1101/2022.02.07.22270651; this version posted February 9, 2022. The copyright holder for this preprint (which was not certified by peer review) is the author/funder, who has granted medRxiv a license to display the preprint in It is made available under a CC-BY-NC-ND 4.0 International license .

29. Mayer, A.R., Ling, J., Mannell, M. V, Gasparovic, C., Phillips, J.P., Doezema, D., Reichard, R., and Yeo, R.A. (2010). A prospective diffusion tensor imaging study in mild traumatic brain injury. Neurology 74, 643-650.

30. Arfanakis, K., Haughton, V.M., Carew, J.D., Rogers, B.P., Dempsey, R.J., and Meyerand, M.E. (2002). Diffusion tensor MR imaging in diffuse axonal injury. Am. J. Neuroradiol. 23, 794-802.

31. Inglese, M., Makani, S., Johnson, G., Cohen, B.A., Silver, J.A., Gonen, O., and Grossman, R.I. (2005). Diffuse axonal injury in mild traumatic brain injury: a diffusion tensor imaging study. J. Neurosurg. 103, 298-303.

32. Smits, M., Houston, G.C., Dippel, D.W.J., Wielopolski, P.A., Vernooij, M.W., Koudstaal, P.J., Hunink, M.G.M., and van der Lugt, A. (2011). Microstructural brain injury in post-concussion syndrome after minor head injury. Neuroradiology 53, 553563.

33. Tournier, J.-D., Calamante, F., and Connelly, A. (2007). Robust determination of the fibre orientation distribution in diffusion MRI: non-negativity constrained superresolved spherical deconvolution. Neuroimage 35, 1459-1472.

34. Assaf, Y., and Basser, P.J. (2005). Composite hindered and restricted model of diffusion (CHARMED) MR imaging of the human brain. Neuroimage 27, 48-58.

35. Behrens, T.E.J., Berg, H.J., Jbabdi, S., Rushworth, M.F.S., and Woolrich, M.W. (2007). Probabilistic diffusion tractography with multiple fibre orientations: What can we gain? Neuroimage 34, 144-155.

36. Raffelt, D.A., Tournier, J.-D., Smith, R.E., Vaughan, D.N., Jackson, G., Ridgway, G.R., and Connelly, A. (2017). Investigating white matter fibre density and morphology using fixel-based analysis. Neuroimage 144, 58-73.

37. McCrory, P.R., Ariens, M., and Berkovic, S.F. (2000). The nature and duration of acute concussive symptoms in Australian football. Clin. J. Sport Med. 10, 235-238.

38. Gibbs, N., and Watsford, M. (2017). Concussion incidence and recurrence in professional Australian football match-play: a 14-year analysis. J. Sports Med. 2017.

39. McNeel, C., Clark, G.M., Davies, C.B., Major, B.P., and Lum, J.A.G. (2020). Concussion incidence and time-loss in Australian football: A systematic review. J. Sci. Med. Sport 23, 125-133.

40. Makdissi, M., McCrory, P., Ugoni, A., Darby, D., and Brukner, P. (2009). A prospective study of postconcussive outcomes after return to play in Australian football. Am. J. Sports Med. 37, 877-883.

41. Makdissi, M., and Davis, G. (2016). The reliability and validity of video analysis for the assessment of the clinical signs of concussion in Australian football. J. Sci. Med. Sport 19, 859-863.

42. Friston, K.J., Ashburner, J.T., Kiebel, S.J., Nichols, T.E., and Penny, W.D. (2007). Statistical parametric mapping: the analysis of functional brain images. London: Academic Press.

43. Tournier, J.-D., Smith, R.E., Raffelt, D.A., Tabbara, R., Dhollander, T., Pietsch, M., Christiaens, D., Jeurissen, B., Yeh, C.-H., and Connelly, A. (2019). MRtrix3: A fast, flexible and open software framework for medical image processing and visualisation. Neuroimage, 551739. 
medRxiv preprint doi: https://doi.org/10.1101/2022.02.07.22270651; this version posted February 9, 2022. The copyright holder for this preprint (which was not certified by peer review) is the author/funder, who has granted medRxiv a license to display the preprint in It is made available under a CC-BY-NC-ND 4.0 International license .

44. Veraart, J., Fieremans, E., and Novikov, D.S. (2016). Diffusion MRI noise mapping using random matrix theory. Magn. Reson. Med. .

45. Kellner, E., Dhital, B., Kiselev, V.G., and Reisert, M. (2016). Gibbs-ringing artifact removal based on local subvoxel-shifts. Magn. Reson. Med. 76, 1574-1581.

46. Andersson, J.L.R., Skare, S., and Ashburner, J. (2003). How to correct susceptibility distortions in spin-echo echo-planar images: application to diffusion tensor imaging. Neuroimage 20, 870-888.

47. Andersson, J.L.R., and Sotiropoulos, S.N. (2016). An integrated approach to correction for off-resonance effects and subject movement in diffusion MR imaging. Neuroimage $125,1063-1078$.

48. Bastiani, M., Cottaar, M., Fitzgibbon, S.P., Suri, S., Alfaro-Almagro, F., Sotiropoulos, S.N., Jbabdi, S., and Andersson, J.L.R. (2019). Automated quality control for within and between studies diffusion MRI data using a non-parametric framework for movement and distortion correction. Neuroimage 184, 801-812.

49. Tustison, N.J., Avants, B.B., Cook, P.A., Zheng, Y., Egan, A., Yushkevich, P.A., and Gee, J.C. (2010). N4ITK: improved N3 bias correction. IEEE Trans. Med. Imaging 29, $1310-1320$.

50. Raffelt, D., Tournier, J.-D., Rose, S., Ridgway, G.R., Henderson, R., Crozier, S., Salvado, O., and Connelly, A. (2012). Apparent fibre density: a novel measure for the analysis of diffusion-weighted magnetic resonance images. Neuroimage 59, 39763994.

51. Dhollander, T., and Connelly, A. (2016). A novel iterative approach to reap the benefits of multi-tissue CSD from just single-shell $(+b=0)$ diffusion MRI data. 24th Int. Soc. Magn. Reson. Med. 24, 3010.

52. Raffelt, D., Tournier, J.-D., Fripp, J., Crozier, S., Connelly, A., and Salvado, O. (2011). Symmetric diffeomorphic registration of fibre orientation distributions. Neuroimage 56, 1171-1180.

53. Raffelt, D., Tournier, J., Crozier, S., Connelly, A., and Salvado, O. (2012). Reorientation of fiber orientation distributions using apodized point spread functions. Magn. Reson. Med. 67, 844-855.

54. Smith, R.E., Tournier, J.-D., Calamante, F., and Connelly, A. (2013). SIFT: sphericaldeconvolution informed filtering of tractograms. Neuroimage 67, 298-312.

55. Collie, A., Makdissi, M., Maruff, P., Bennell, K., and McCrory, P. (2006). Cognition in the days following concussion: comparison of symptomatic versus asymptomatic athletes. J. Neurol. Neurosurg. Psychiatry 77, 241-245.

56. Makdissi, M., Darby, D., Maruff, P., Ugoni, A., Brukner, P., and McCrory, P.R. (2010). Natural history of concussion in sport: markers of severity and implications for management. Am. J. Sports Med. 38, 464-471.

57. Collie, A., Maruff, P., Makdissi, M., McCrory, P., McStephen, M., and Darby, D. (2003). CogSport: reliability and correlation with conventional cognitive tests used in postconcussion medical evaluations. Clin. J. Sport Med. 13, 28-32.

58. Raffelt, D.A., Smith, R.E., Ridgway, G.R., Tournier, J.-D., Vaughan, D.N., Rose, S., Henderson, R., and Connelly, A. (2015). Connectivity-based fixel enhancement: Whole-brain statistical analysis of diffusion MRI measures in the presence of crossing 
medRxiv preprint doi: https://doi.org/10.1101/2022.02.07.22270651; this version posted February 9, 2022. The copyright holder for this preprint (which was not certified by peer review) is the author/funder, who has granted medRxiv a license to display the preprint in It is made available under a CC-BY-NC-ND 4.0 International license .

fibres. Neuroimage 117, 40-55.

59. Nichols, T.E., and Holmes, A.P. (2002). Nonparametric permutation tests for functional neuroimaging: a primer with examples. Hum. Brain Mapp. 15, 1-25.

60. Zhang, L., Heier, L.A., Zimmerman, R.D., Jordan, B., and Uluğ, A.M. (2006). Diffusion anisotropy changes in the brains of professional boxers. Am. J. Neuroradiol. 27, 2000-2004.

61. Chamard, E., Lassonde, M., Henry, L., Tremblay, J., Boulanger, Y., De Beaumont, L., and Théoret, H. (2013). Neurometabolic and microstructural alterations following a sports-related concussion in female athletes. Brain Inj. 27, 1038-1046.

62. Reeves, T.M., Phillips, L.L., and Povlishock, J.T. (2005). Myelinated and unmyelinated axons of the corpus callosum differ in vulnerability and functional recovery following traumatic brain injury. Exp. Neurol. 196, 126-137.

63. Viano, D.C., Casson, I.R., Pellman, E.J., Zhang, L., King, A.I., and Yang, K.H. (2005). Concussion in professional football: brain responses by finite element analysis: part 9. Neurosurgery 57, 891-916.

64. Cubon, V.A., Putukian, M., Boyer, C., and Dettwiler, A. (2011). A diffusion tensor imaging study on the white matter skeleton in individuals with sports-related concussion. J. Neurotrauma 28, 189-201.

65. Hurley, R.A., McGowan, J.C., Arfanakis, K., and Taber, K.H. (2004). Traumatic axonal injury: novel insights into evolution and identification. J. Neuropsychiatry Clin. Neurosci. 16, 1-7.

66. Zappala, G., de Schotten, M.T., and Eslinger, P.J. (2012). Traumatic brain injury and the frontal lobes: what can we gain with diffusion tensor imaging? Cortex 48, 156165.

67. Barrick, T.R., Lawes, I.N., Mackay, C.E., and Clark, C.A. (2007). White matter pathway asymmetry underlies functional lateralization. Cereb. Cortex 17, 591-598.

68. Büchel, C., Raedler, T., Sommer, M., Sach, M., Weiller, C., and Koch, M.A. (2004). White matter asymmetry in the human brain: a diffusion tensor MRI study. Cereb. cortex 14, 945-951.

69. Pedersen, M., Makdissi, M., Parker, D.M., Barbour, T., Abbott, D.F., McCrory, P., and Jackson, G.D. (2020). Quantitative MRI as an imaging marker of concussion: evidence from studying repeated events. Eur. J. Neurol. 27, e53-e54.

70. Tang-Schomer, M.D., Patel, A.R., Baas, P.W., and Smith, D.H. (2010). Mechanical breaking of microtubules in axons during dynamic stretch injury underlies delayed elasticity, microtubule disassembly, and axon degeneration. FASEB J. 24, 1401-1410.

71. Wang, J., Hamm, R.J., and Povlishock, J.T. (2011). Traumatic axonal injury in the optic nerve: evidence for axonal swelling, disconnection, dieback, and reorganization. J. Neurotrauma 28, 1185-1198.

72. Maxwell, W.L., Povlishock, J.T., and Graham, D.L. (1997). A mechanistic analysis of nondisruptive axonal injury: a review. J. Neurotrauma 14, 419-440.

73. Donovan, V., Kim, C., Anugerah, A.K., Coats, J.S., Oyoyo, U., Pardo, A.C., and Obenaus, A. (2014). Repeated mild traumatic brain injury results in long-term whitematter disruption. J. Cereb. Blood Flow Metab. 34, 715-723. 
medRxiv preprint doi: https://doi.org/10.1101/2022.02.07.22270651; this version posted February 9, 2022. The copyright holder for this preprint (which was not certified by peer review) is the author/funder, who has granted medRxiv a license to display the preprint in It is made available under a CC-BY-NC-ND 4.0 International license .

74. $\quad$ Ling, J.M., Pena, A., Yeo, R.A., Merideth, F.L., Klimaj, S., Gasparovic, C., and Mayer, A.R. (2012). Biomarkers of increased diffusion anisotropy in semi-acute mild traumatic brain injury: a longitudinal perspective. Brain 135, 1281-1292.

75. Wilde, E.A., McCauley, S.R., Hunter, J. V, Bigler, E.D., Chu, Z., Wang, Z.J., Hanten, G.R., Troyanskaya, M., Yallampalli, R., and Li, X. (2008). Diffusion tensor imaging of acute mild traumatic brain injury in adolescents. Neurology 70, 948-955.

76. Lipton, M.L., Kim, N., Park, Y.K., Hulkower, M.B., Gardin, T.M., Shifteh, K., Kim, M., Zimmerman, M.E., Lipton, R.B., and Branch, C.A. (2012). Robust detection of traumatic axonal injury in individual mild traumatic brain injury patients: intersubject variation, change over time and bidirectional changes in anisotropy. Brain Imaging Behav. 6, 329-342.

77. Liang, D., Bhatta, S., Gerzanich, V., and Simard, J.M. (2007). Cytotoxic edema: mechanisms of pathological cell swelling. Neurosurg. Focus 22, 1-9.

78. Farkas, O., and Povlishock, J.T. (2007). Cellular and subcellular change evoked by diffuse traumatic brain injury: a complex web of change extending far beyond focal damage. Prog. Brain Res. 161, 43-59.

79. Shin, W., Mahmoud, S.Y., Sakaie, K., Banks, S.J., Lowe, M.J., Phillips, M., Modic, M.T., and Bernick, C. (2014). Diffusion measures indicate fight exposure-related damage to cerebral white matter in boxers and mixed martial arts fighters. Am. J. Neuroradiol. 35, 285-290.

80. Vos, S.B., Jones, D.K., Viergever, M.A., and Leemans, A. (2011). Partial volume effect as a hidden covariate in DTI analyses. Neuroimage 55, 1566-1576.

81. Budde, M.D., Janes, L., Gold, E., Turtzo, L.C., and Frank, J.A. (2011). The contribution of gliosis to diffusion tensor anisotropy and tractography following traumatic brain injury: validation in the rat using Fourier analysis of stained tissue sections. Brain 134, 2248-2260.

82. Jolly, A.E., Bălăeţ, M., Azor, A., Friedland, D., Sandrone, S., Graham, N.S.N., Zimmerman, K., and Sharp, D.J. (2020). Detecting axonal injury in individual patients after traumatic brain injury. Brain .

83. Shenton, M.E., Price, B.H., Levin, L., and Edersheim, J.G. (2018). Mild traumatic brain injury: Is DTI ready for the courtroom? Int. J. Law Psychiatry 61, 50-63.

84. Stokum, J.A., Sours, C., Zhuo, J., Kane, R., Shanmuganathan, K., and Gullapalli, R.P. (2015). A longitudinal evaluation of diffusion kurtosis imaging in patients with mild traumatic brain injury. Brain Inj. 29, 47-57.

85. Churchill, N.W., Caverzasi, E., Graham, S.J., Hutchison, M.G., and Schweizer, T.A. (2017). White matter microstructure in athletes with a history of concussion:

Comparing diffusion tensor imaging (DTI) and neurite orientation dispersion and density imaging (NODDI). Hum. Brain Mapp. 38, 4201-4211.

86. Churchill, N.W., Caverzasi, E., Graham, S.J., Hutchison, M.G., and Schweizer, T.A. (2019). White matter during concussion recovery: Comparing diffusion tensor imaging (DTI) and neurite orientation dispersion and density imaging (NODDI). Hum. Brain Mapp. 40, 1908-1918.

87. Lancaster, M.A., Olson, D. V, McCrea, M.A., Nelson, L.D., LaRoche, A.A., and Muftuler, L.T. (2016). Acute white matter changes following sport-related concussion: 
medRxiv preprint doi: https://doi.org/10.1101/2022.02.07.22270651; this version posted February 9, 2022. The copyright holder for this preprint (which was not certified by peer review) is the author/funder, who has granted medRxiv a license to display the preprint in It is made available under a CC-BY-NC-ND 4.0 International license .

A serial diffusion tensor and diffusion kurtosis tensor imaging study. Hum. Brain Mapp. 37, 3821-3834.

88. Palacios, E.M., Owen, J.P., Yuh, E.L., Wang, M.B., Vassar, M.J., Ferguson, A.R., Diaz-Arrastia, R., Giacino, J.T., Okonkwo, D.O., and Robertson, C.S. (2020). The evolution of white matter microstructural changes after mild traumatic brain injury: a longitudinal DTI and NODDI study. Sci. Adv. 6, eaaz6892.

89. Dhollander, T., Clemente, A., Singh, M., Boonstra, F., Civier, O., Duque, J.D., Egorova, N., Enticott, P., Fuelscher, I., and Gajamange, S. (2021). Fixel-based analysis of diffusion MRI: methods, applications, challenges and opportunities. Neuroimage , 118417.

90. Wright, D.K., Johnston, L.A., Kershaw, J., Ordidge, R., O’Brien, T.J., and Shultz, S.R. (2017). Changes in apparent fiber density and track-weighted imaging metrics in white matter following experimental traumatic brain injury. J. Neurotrauma 34, 2109-2118.

91. Liang, X., Yeh, C.-H., Poudel, G., Swinnen, S.P., and Caeyenberghs, K. (2021). Longitudinal fixel-based analysis reveals restoration of white matter alterations following balance training in young brain-injured patients. NeuroImage Clin. 30, 102621.

92. Wallace, E.J., Mathias, J.L., Ward, L., Fripp, J., Rose, S., and Pannek, K. (2020). A fixel-based analysis of micro-and macro-structural changes to white matter following adult traumatic brain injury. Hum. Brain Mapp. 41, 2187-2197.

93. Wright, D.K., Symons, G.F., O’Brien, W.T., McDonald, S.J., Zamani, A., Major, B., Chen, Z., Costello, D., Brady, R.D., and Sun, M. (2021). Diffusion imaging reveals sex differences in the white matter following sports-related concussion. Cereb. cortex .

94. Iverson, G.L., Gaetz, M., Lovell, M.R., and Collins, M.W. (2004). Cumulative effects of concussion in amateur athletes. Brain Inj. 18, 433-443.

95. Thériault, M., De Beaumont, L., Tremblay, S., Lassonde, M., and Jolicoeur, P. (2011). Cumulative effects of concussions in athletes revealed by electrophysiological abnormalities on visual working memory. J. Clin. Exp. Neuropsychol. 33, 30-41. 
medRxiv preprint doi: https://doi.org/10.1101/2022.02.07.22270651; this version posted February 9, 2022. The copyright holder for this preprint (which was not certified by peer review) is the author/funder, who has granted medRxiv a license to display the preprint in It is made available under a CC-BY-NC-ND 4.0 International license

\section{Tables}

Table 1: Overview of mTBI participants and controls

\begin{tabular}{|c|c|c|c|c|}
\hline & $\begin{array}{l}\text { Acute mTBI } \\
(n=15)\end{array}$ & $\begin{array}{l}\text { Subacute } \\
\text { mTBI } \\
(n=15)\end{array}$ & $\begin{array}{l}\text { Controls } \\
(n=\mathbf{3 0})\end{array}$ & Statistic, $P$-value \\
\hline Age (years) & $23.9(3.4)$ & $25.2(3.4)$ & $24.0(4.7)$ & $\mathrm{F}(2,57)=0.46, P=0.637$ \\
\hline $\begin{array}{l}\text { Intracranial volume } \\
\left(\mathrm{cm}^{3}\right)\end{array}$ & $1550.4(103)$ & $1622.9(137)$ & $1535.1(122)$ & $\mathrm{F}(2,57)=2.66, P=0.078$ \\
\hline DWI motion ${ }^{\mathrm{b}}(\mathrm{mm})$ & $0.62(0.25)$ & $0.53(0.17)$ & $0.63(0.18)$ & $\mathrm{F}(2,57)=1.27, P=0.289$ \\
\hline Days since injury (days) & $7.5(3.2)$ & $34.3(19.4)$ & - & $\mathrm{t}(28)=5.29, P=0.002$ \\
\hline $\begin{array}{l}\text { Professional sporting } \\
\text { career (years) }\end{array}$ & $5.87(3.62)$ & $6.13(2.84)$ & - & $\mathrm{t}(28)=-0.21, P=0.838$ \\
\hline $\begin{array}{l}\text { Cognitive assessments } \\
\text { available at time of MRI }\end{array}$ & $\mathrm{n}=12$ & $\mathrm{n}=11$ & & \\
\hline CogSport $^{\mathrm{c}}$ & & & & \\
\hline Simple reaction time & $93.34(6.73)$ & $85.81(13.86)$ & - & $\mathrm{t}(14)=1.54, P=0.146$ \\
\hline Complex reaction time & $99.65(10.96)$ & $92.65(10.66)$ & - & $\mathrm{t}(21)=1.55, P=0.136$ \\
\hline One-back & $102.59(11.22)$ & $99.25(7.58)$ & - & $\mathrm{t}(19)=0.84, P=0.41$ \\
\hline Learning & $97.38(12.40)$ & $98.29(7.08)$ & - & $\mathrm{t}(18)=-0.22, P=0.83$ \\
\hline \multicolumn{5}{|c|}{ antracranial volume computed using SPM12. } \\
\hline \multicolumn{5}{|c|}{ bDWI motion computed using FSL's eddy QC tool (Bastiani et al., 2019). } \\
\hline \multicolumn{5}{|c|}{${ }^{\mathrm{c}}$ CogSport measures are provided as normative scores. } \\
\hline \multicolumn{5}{|c|}{ Reported statistics and $P$-values are from one-way between-groups ANOVA for age, intracranial volume, and } \\
\hline
\end{tabular}




\section{Figures}

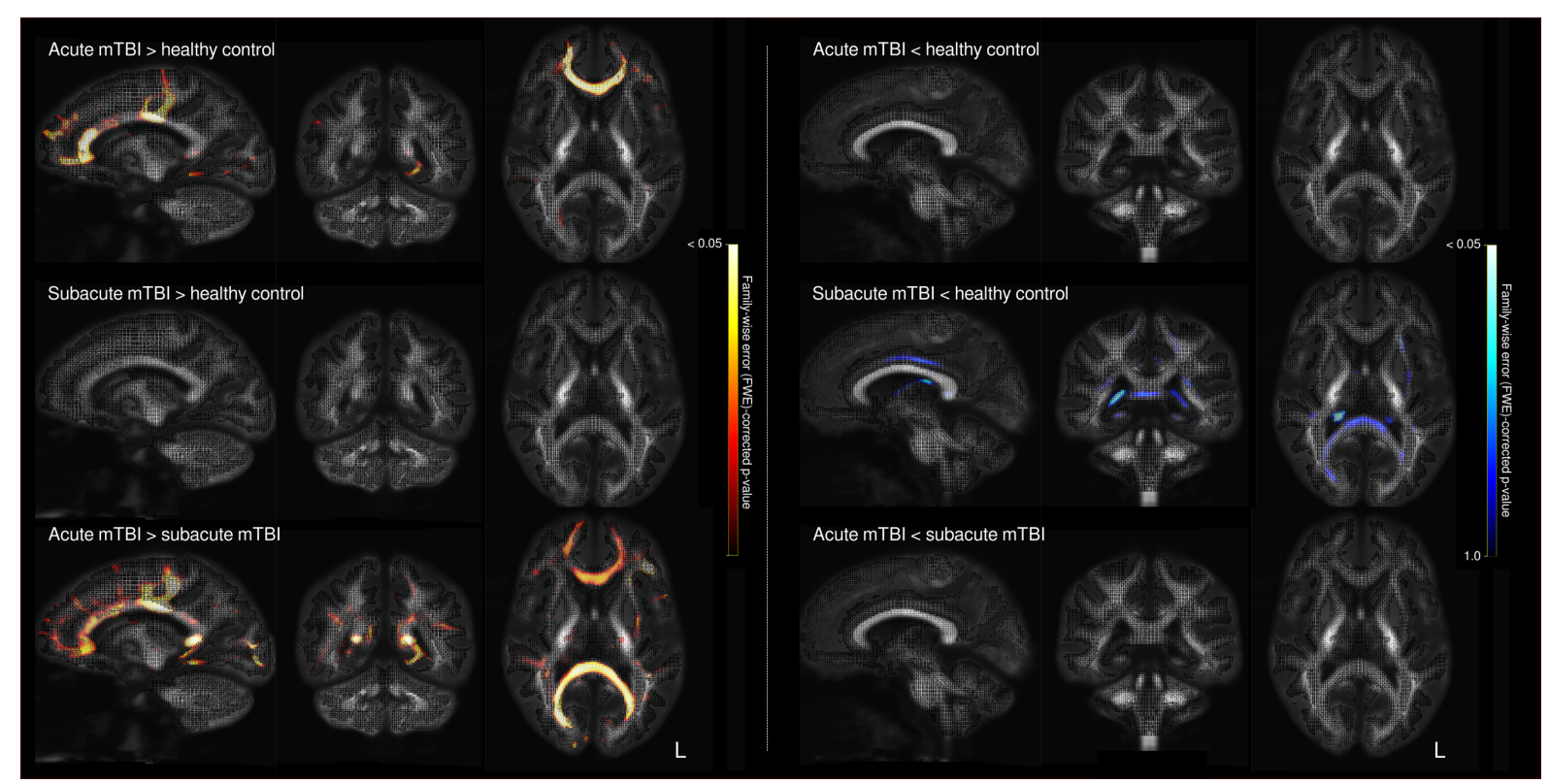

Figure 1: Fixel-based analysis results for fibre density and cross-section in acute and subacute mTBI. Whole-brain fixel-based analysis was performed to compare the acute mTBI, subacute mTBI and neurologically healthy control groups. The results of these whole-brain analyses are shown for the fibre density and cross-section (FDC) metric, on a single sagittal, coronal and axial slice. Fixels (specific fibre populations within a voxel) are unthresholded and coloured by family-wise error (FWE) corrected p-value. As can be appreciated from these comparisons, increased FDC was observed in the acute mTBI cohort, when compared to both the control and subacute mTBI groups, particularly in callosal fibre structures. In contrast, subtle decreases in FDC were apparent in the subacute, but not acute, mTBI group, although these did not survive multiple comparison correction. 


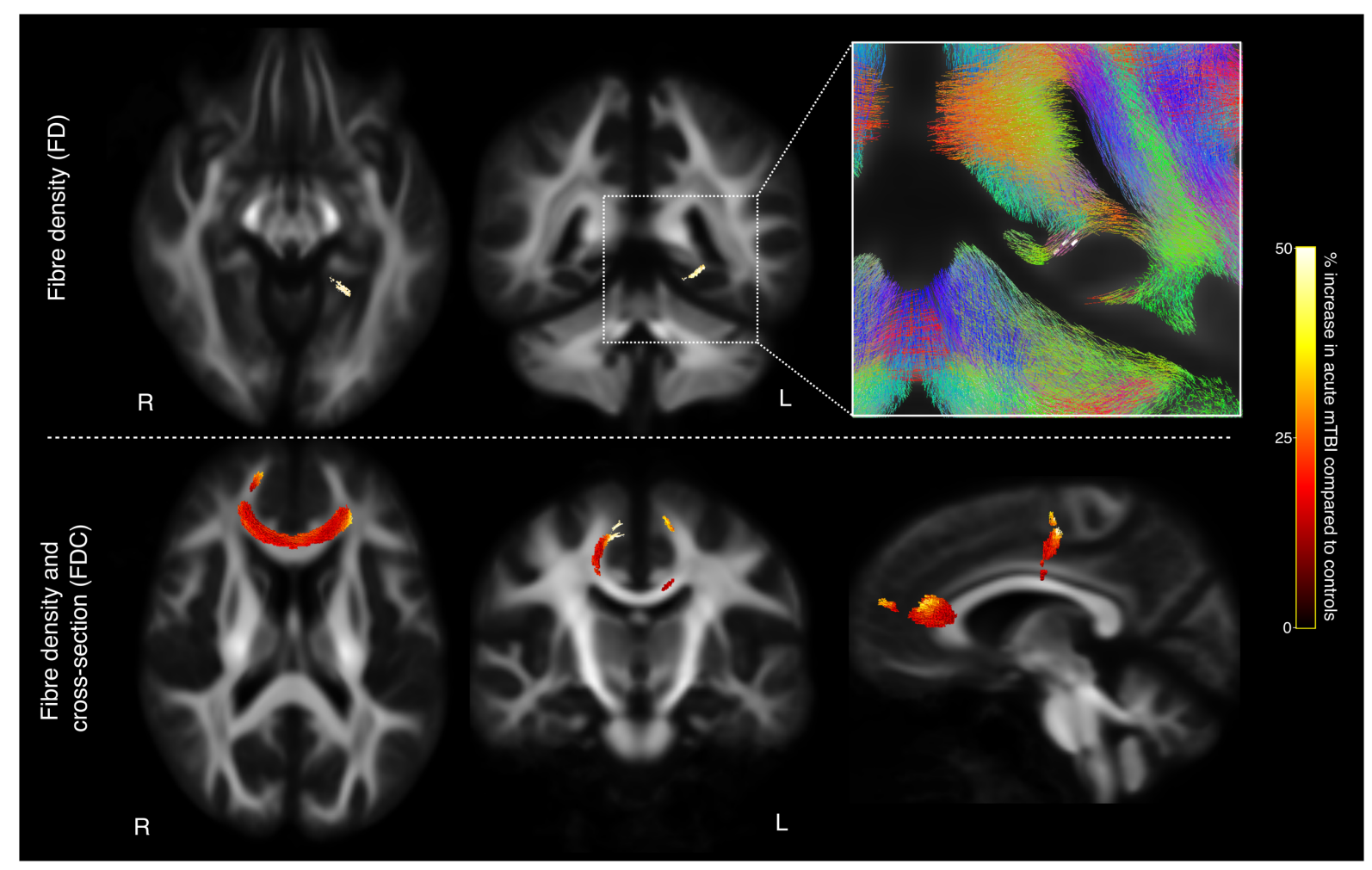

Figure 2: Fibre tracts exhibiting significant abnormalities in acute mTBI. Top row: acute mTBI participants exhibited significant (FWE-corrected p-value $<0.05$ ) increases in fibre density (FD) within select fixels in the left parahippocampal white matter. These fixels are mapped onto the template tractogram and shown on axial and coronal slices at $10 \mathrm{~mm}$ increments and are coloured by their percentage increase in the acute mTBI group compared to controls. The inset on the right shows the affected fixels (white lines), with the template tractogram overlaid. Bottom row: significant increases in the fibre density and cross-section (FDC) metric were observed in the acute mTBI group compared to controls, in the genu and body of the corpus callosum. These fixels are again mapped onto the template tractogram, with the axial slice displaying the tract streamlines at $10 \mathrm{~mm}$ increments corresponding to the affected fixels in the genu, and the coronal slice displaying the streamlines corresponding to the affected fixels in the body of the corpus callosum. The right image shows a sagittal slice with all affected streamlines displayed. 


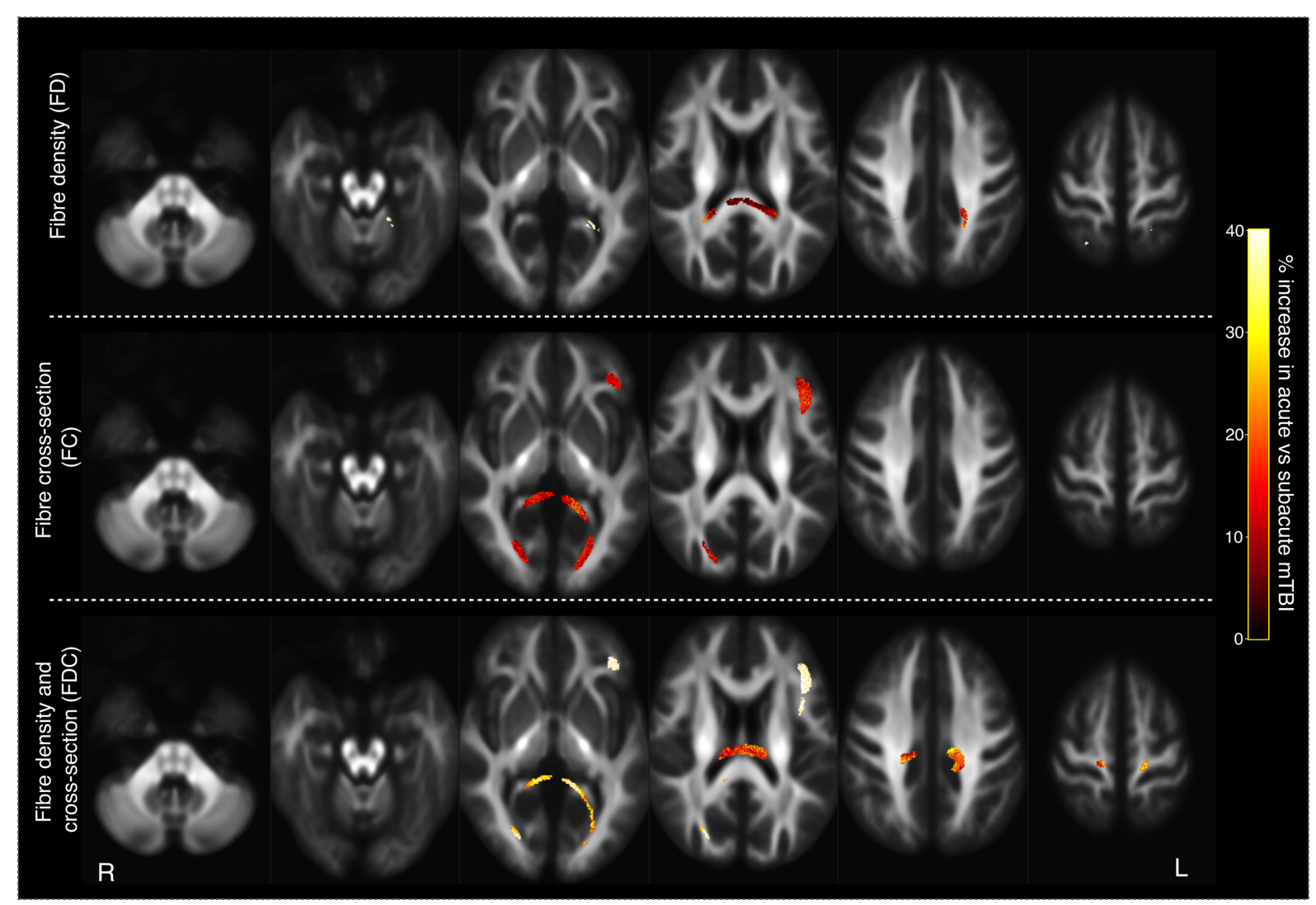

Figure 3: Fibre tracts exhibiting significant differences between the acute and subacute

mTBI groups. Fixels exhibiting significant increases in the acute mTBI group when compared to the subacute mTBI group are mapped onto the template tractogram. Significantly affected streamlines are displayed for fibre density (FD; top), fibre cross-section (FC; middle), and fibre density and cross-section (FDC; bottom), and are coloured by the percentage increase in the acute mTBI group compared to the subacute group. For the FD metric, the splenium of the corpus callosum, and the left parahippocampal white matter exhibited significant increases in the acute mTBI group, while for the FC metric, the splenium and the left frontal white matter in the superior longitudinal fasciculus exhibited significant increases. The splenium and body of the corpus callosum, along with the left frontal white matter was affected in the acute mTBI group for FDC metric. 


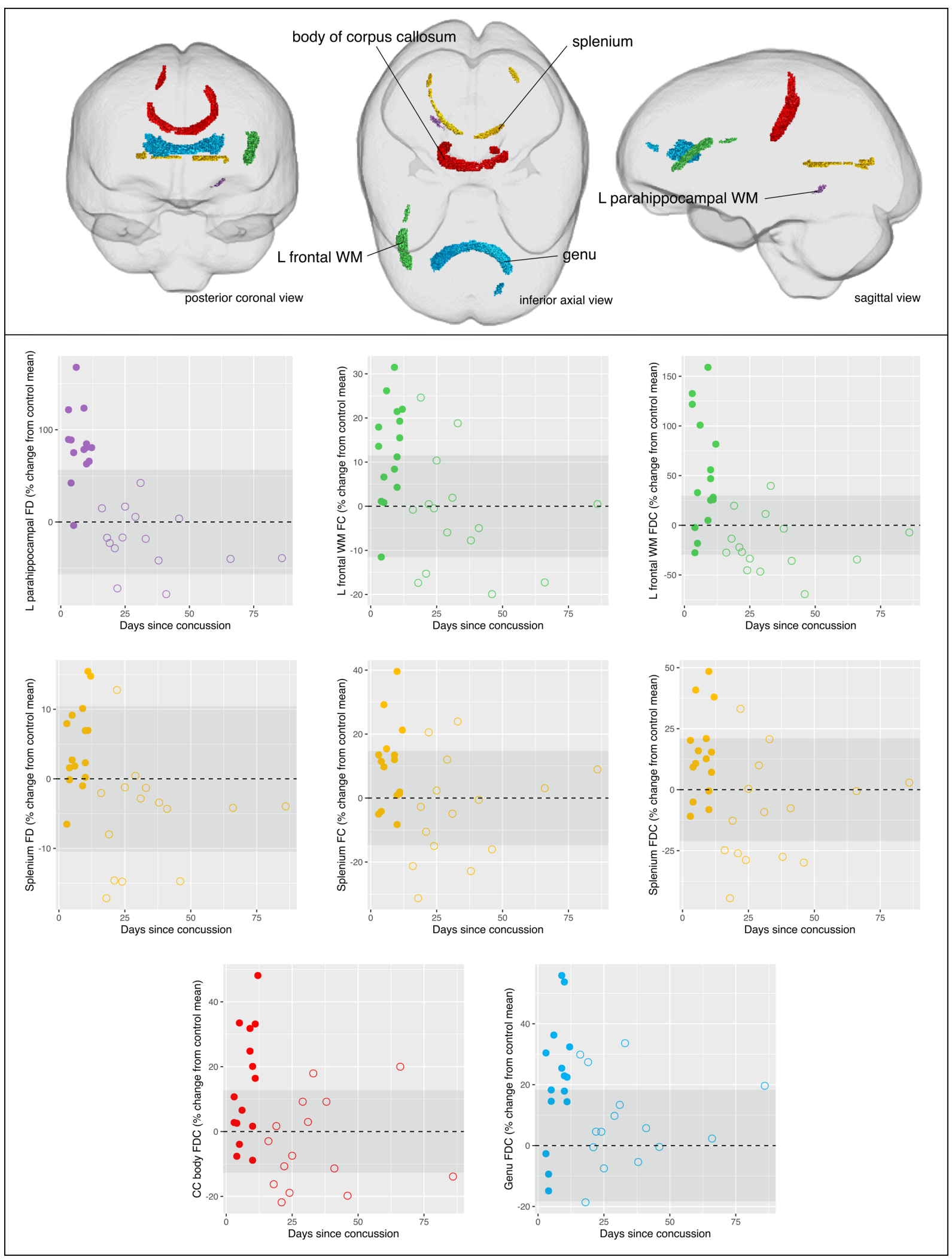

Figure 4: Tracts-of-interest. Top panel: fixels that exhibited significant increases in acute mTBI compared to either controls or subacute mTBI were categorised into five tracts-ofinterest. These tracts are shown in coronal, axial, and sagittal glass brain representations, and coloured by the tract to which they belong. Mean fixel-based metrics were computed in these 
medRxiv preprint doi: https://doi.org/10.1101/2022.02.07.22270651; this version posted February 9, 2022. The copyright holder for this preprint (which was not certified by peer review) is the author/funder, who has granted medRxiv a license to display the preprint in It is made available under a CC-BY-NC-ND 4.0 International license.

tracts for each mTBI participant for exploratory post-hoc analyses. Bottom panel: scatterplots show the mean fibre density and/or cross-section in each tract of interest, plotted against days since concussion. Data points correspond to individual subjects, with solid circles representing acute mTBI participants, and unfilled circles representing subacute mTBI participants. No significant association was observed between fixel-based metrics and days since injury within the acute mTBI group. For all scatterplots, fixel-based metrics are expressed as percentage (\%) change from the control group mean (the dotted line indicating control mean, and the shaded area showing control group standard deviation). 


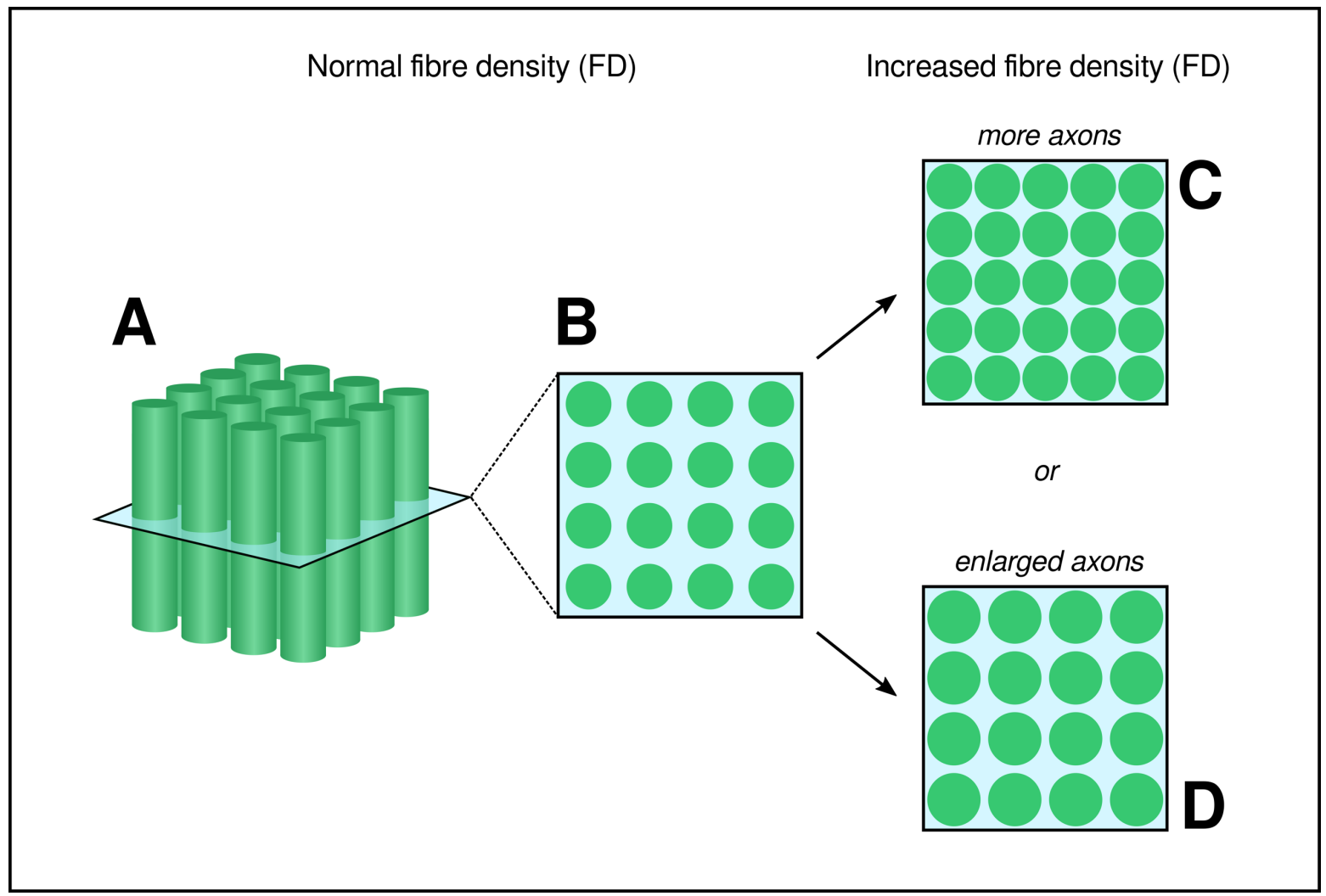

Figure 5: Schematic figure showing potential causes of increased fibre density (FD). (A) and (B) are adapted from Raffelt et al. $(2012)^{50}$, where (A) shows a depiction of axons that are coherently ordered within a single imaging voxel, and (B) shows the perpendicular plane through (A). For DWI data with high $b$-values such as those acquired in this study $(b=3000$ $\mathrm{s} / \mathrm{mm}^{2}$ ), the fibre density (FD) metric is approximately proportional to the volume of the intracellular component of axons oriented in a given direction (shown in green in B). Increases in the fibre density (FD) value could arise if there is an increase in the volume of the intracellular component; for example, if there are more axons (C), or if there is increased intracellular volume occupied by the same number of axons (D). In the present study, the observed increase in FD is likely to reflect increased axonal volume in the absence of change to the number of axons (i.e. (D)). Provided that axonal diameters stay within the normal range $(\leq 6 \mu \mathrm{m})$, this increase in FD is entirely compatible with cytotoxic oedema, whereby increased permeability of the axonal membrane can result in axonal swelling. 